\title{
MONOCULTURALISM IN NIGERIA: A STUDY OF A GIANT ECONOMY THAT LACKS LEADERSHIP, 1957-2019
}

\author{
Abuoma C. Agajelu* \\ \& \\ Oluchukwu N. Orizu* \\ http://dx.doi.org/10.4314/og.v15i1.5s
}

\begin{abstract}
Sustainable industrialisation has practically evaded Nigeria, the efforts towards that direction notwithstanding. There are obvious policies and programmes designed to encourage industrial-based economy in the country. Of course, if achieved, industrialisation would ensure diversification and the country could save itself from the stranglehold of economic monoculturism. Nonetheless, "oil money" appears to be a cog in the wheel of progress in that direction (in essence, the direction of economic diversification). Basically, a country would not be able to achieve industrialisation and economic diversification when the state craft is repeatedly piloted by leaders with monocultural mentality. A lot of literature may exist on the failures and inadequacies of Nigerian leaders as the cause of the country's economic backwardness. Nonetheless, it appears that the searchlight has not been adequately beamed on the monocultural attitude and mentality of those who constitute the leaders over the years. As would be shown in this paper, the monocultural attitude of the leaders has a ripple effect on the economic milieu of the country. Considering this gap, this paper employs the eclectic method of analysis to examine the leadership factors which have been militating against economic policy implementation in a rather promising economy. The paper explicates the nature of Nigerian economy, showing its potentials and investigating on the factors impeding the identified potentials.
\end{abstract}

\section{Introduction}

Nigeria is regarded as one of the largest economies in Africa. However, the country is a monoculture economy, especially since the discovery of crude petroleum, first in Olobiri, a community located in the present day Bayelsa State, in the late 1950s and the subsequent exploration of the resource in commercial quantity. The 
discovery of petroleum in an age when industrialisation was basically powered by the resource appeared to be an obvious blessing. Therefore, it was expected that the leaders of Nigeria, at the time when crude oil was explored in commercial quantity, take advantage of the huge revenue accruable from the exportation of the resource to put the country's economy on the part of sustainable development through diversification. Unfortunately, empirical observations have shown that numerous factors have kept the country from achieving the desired economic diversification. One of such factors is lack of innovative approach in economic policy making. In essence, the leaders have a monoculture approach to economic policies and programmes.

The monoculture trait of Nigerian leaders reflects on their attitude towards any sector of the economy that was not petroleum. There have been numerous efforts to improve agriculture, industry and trade in non-petroleum goods as could be seen in this paper. There are equally cases of efforts to increase non-petroleum exports. These efforts are shown in the attractive government economic policies and programmes. Unfortunately, these policies and programmes mostly lacked the will power to implement them. This lack of will power can be blamed on the huge oil revenue that basically corrupted the mind of the leaders. What is more, the leaders have mostly shown to lack patriotism, which is a primary prerequisite for progressive and selfless leadership. All these come together to shape the monoculture attitude of Nigerian leaders over the years. This study delves into explicating how the monoculture attitude of the Nigerian leaders has perpetrated a monoculture economy that made the country a crippled giant.

\section{The Emergence of Crude Oil Economy and the Decline of Agriculture}

Before oil took the centre stage of the Nigerian economy, the country had depended on agricultural production for its major exports. By 1958, agriculture contributed $68 \%$ of gross domestic product (GDP) of the country. (Lawal, 1997) However, agricultural productivity consistently declined since 1970 .

Generally, the popular agricultural export produce from Nigeria, especially before independence, were palm produce, groundnuts and cotton (Udo and Falola, 2010). Nonetheless, there 
Agajelu \& Orizu: Monoculturalism in Nigeria...

were a plethora of agricultural produce that had appreciable export value apart from those mentioned above. Each region of the country is known to specialise in specific products, basically because of the climatic conditions inherent which allows for such production. In the north, peasant farmers produced cereals, sorghum, rice, groundnuts, cotton, millet and some wheat. On its own side, the south is known to have specialised in root and tree crops like yam, cassava, citrus fruits, palm produce, kolanuts, cocoa and rubber. According to A.A. Lawal (1997), despite their reliance on traditional methods of shifting cultivation and the use of traditional implements, peasant farmers produced $70 \%$ of Nigeria's exports and $95 \%$ of food requirements. Considering the statement credited to Lawal, Nigeria had overtly relied on crude farming methods, which involved the use of non-mechanised tools and implements. This was an early sign of monoculturism that may have discouraged the agrarian economy, in furtherance serving as a foundation for its abandonment at the wake of petroleum oil exploration. Had the leadership of the country extricated itself from the monoculture mentality in the economic sphere of the country, maybe method of cultivation and agricultural productivity may have been improved in line with modern methods and the overt reliance on the crude oil at the dawn of commercial oil exploration may not have happened.

A major nail on the coffin of agricultural production in Nigeria and in furtherance, economic diversification, was the rise in oil price in the 1970s. The event of rise in oil price precipitated high revenue for the country through petroleum oil exportation. The country became so wealthy that General Yakubu Gowon, who was Nigeria's military head of states in the early 1970s, reportedly declared that Nigeria had so much money that it did not know how to spend (Nwankwo, 1999). The statement credited to Gowon may have explained why his government failed to adequately invest on, and implement some of the agricultural programmes of his regime with the huge oil revenue accruable to the coffers of the country. This was another clear case of impaired leadership. Instead of looking inwards to diversify the economy through mechanisation of agriculture, the Nigerian government at the time took up the stance of "father Christmas" for its West African neighbours. Even the Gowon's Second National Development Plan appears to have neglected agriculture because it was not found as one of the main 
Ogirisi: a new journal of African studies vol. 15s 2019

objectives of the Plan (Ojiakor, 2014). The long term effect of this neglect was the establishment of an economy that depended on petroleum products and aids from donor actors in the international system. Of course there were efforts by subsequent governments to reawaken the agricultural sector of the economy, but these efforts had traces of monoculture attitude which impaired their implementation.

\section{Monoculture, Leadership and Impaired Industrialisation in Nigeria}

The Nigerian practice of monocultural economy does not only affect the agricultural sector, but also rubs off negatively on the industrial sector of the nation's economy. A passive observation of Nigerian economy may indicate a total dearth and neglect of the industrial sector by the government. Even though successive governments appear to have been prioritising industrialisation in their economic policy objectives, their implementations have left much to be desired.

However, the neglect of industry or the manufacturing sector of the Nigerian economy does not have a historical antecedent beyond the colonial times. Before and during colonialism, different areas of Nigeria evolved elaborate indigenous manufacturing sector as could be allowed and supported by their prevailing environmental exigencies. The environment as a factor in the nature of industry that flourished in a given part of the country before the contemporary times is explained by Olufemi Ekundare (1973) in the following words:

Natural and geographical factors dictated the location of industries in Nigeria. The canoe industry developed along the coastal areas and the river banks...cotton had been grown and manufactured into cloth for many centuries past. Spun, handwoven in simple cloth and dyed with colours obtained from native plants, it provided most of the clothing of the people. Nearly all the ginning, spinning and weaving equipment was made of wood. There were two types of loom. The one used by men was a narrow upright type worked with pedals, and was commonly adopted all over 
Agajelu \& Orizu: Monoculturalism in Nigeria...

Northern Nigeria... Long before the nineteenth century, the people of Nigeria had been mining iron, tin, gold, salt and other minerals. Ironworks existed in many areas, including Ijebu-Ode, Ilorin, Bida and Awka.

Apart from explicating the environmental factor in manufacturing, Ekundare (1973) goes on to provide an insight on the industrial sector of the pre-colonial and pre-independence Nigerian economy. Unfortunately, the elaborate industrial foundation laid over the years, which depicts the independent ingenuity of the Nigerian indigenous manufacturers, was laid for sacrifice on the altar of crude petroleum. Of course, many scholars believe that the neglect in the post-independence industrial sector was precipitated by the colonial deliberate efforts to ensure the de-industrialisation of the country. In as much as this assertion remains valid, the country obviously had the opportunity to effect sustainable industrialisation with the revenue from petroleum during the days of oil boom, but the investment on industrialisation by the successive governments appeared to have yielded minimal results and the attitude of governmental officials shows a people who have been overwhelmed by the oil revenue that other aspects of the country's industry remained neglected. The situation provided the foundation for the dependency on aid and international donors and an insight on the monoculture attitude of Nigerian leaders.

Of course, as inferred in the previous paragraph, there were visible attempts made by successive governments to achieve industrialisation in Nigeria. Evidence shows that revenue from petroleum exports had over the years been channeled towards industrial development but, as would be shown in this section, obvious cases of corruption, ineptitude, incompetence, nepotism and gross mismanagement, among other maladies, have affected the productivity of the efforts towards industrialisation. The attention given to industrialisation in the post-colonial Nigeria could be gleaned through the words of Onwuka Njoku (2014) which goes as follows:

The immediate post-colonial government's dream of industrializing the economy was supported with a package of facilitative measures and incentives 
designed to create a favorable investment climate in the country. These involved legislative enactments, institutional reforms and infrastructural improvements. Nigeria's industrial potentials were also advertised overseas in order to woo foreign investors. At home, various laws were passed which gave, some critics have argued, "over-generous tax reliefs" to foreign investors and allowed them to repatriate their profits and even capital almost at will.

Also, the industrialisation of the economy became one of the key objectives of the First National Development Plan, 1962-1968. In that development plan, government planned investment on manufacturing was 13.4 percent of total spending. The Second National Development Plan, 1970-1974 also attempted to promote industrialisation by rectifying the lopsided distribution and location of industries. Furthermore, A.A. Lawal (1997) notes that the consistent support of government for further industrialisation in the Third National Development Plan between the 1970s and 1980s stimulated rapid growth and investment in output, employment and a number of industrial plants which concentrated on production of light consumer goods like cotton, textile, beer, cement and paints.

There were also some other immediate gains accrued from the industrial or manufacturing sector with the implementation of some of the measures that were adopted to boost the sector. Contributions of the sector to the growth of the country's Gross Domestic Product (GDP) experienced steady growth, especially up to 1983. According to statistics, the sector contributed 4 percent of the country's GDP in $1958-1959$; 6 percent in 1963-1964; 9 percent in 1969-1969; 16 percent in 1982; 18.2 percent in 1983; 7.4 percent in 1993; and 6.9 percent in 1994 and the percentage kept dwindling up to the close of the $20^{\text {th }}$ century (Njoku, 2014). It is significant to note that the contributions of the industrial sector began to nosedive by 1993, and the year falls within the scope of this study. Events show that the period marked the peak of political instability in the country, precipitated by military coup d'état and the concomitant truncation of existing economic programmes. 
Agajelu \& Orizu: Monoculturalism in Nigeria...

The last sentence of the indented quotation above, as credited to Njoku, underscores another force that bedevils the Nigerian economy. That force is overt dependence on foreign investment, which is considered by dependency theorists as a factor of neo-colonialism. Foreign investment is a basic ingredient of economic growth in the world of free trade. However, Nigeria appears to lack the bargaining power to influence the terms of trade to its favour.

The failure to develop the manufacturing or industrial sector of the Nigerian economy is exemplified in the gloom that befell the attempt to establish a sustainable steel industry in the country. This situation is succinctly captured by Njoku (2014) in the following words, "The story of the Ajaokuta Steel Company exemplifies most of the indices of Nigeria's industrial calamity..." The Ajaokuta steel complex has turned out to be a monument reminding the nation of its failure in the industrial sector and the wastefulness of monoculturism. Of course, the government had a juicy plan towards the project, considering the place of steel in industrial development. It was made clear that the benefits of a steel industry would include the provision of materials for a wide range of industrial and construction works. This would go further to ensure local content in manufacturing and also help to achieve import substitution, thereby promising favourable balance of payment. In examining the idea of developing a steel industry in Nigeria and the construction of the Ajaokuta steel complex, it is important to note that some European firms contracted in 1958 to study the feasibility of a viable steel industry in Nigeria returned a negative verdict. One sticking point was the quality of Nigerian coal and iron ore. However, a Russian firm was subsequently contracted for same feasibility study and their verdict was positive. According to Njoku (2014), the Russian firm may have told the Nigerian government what it preferred to hear.

With the Russian firm beaming a green light on the viability of steel industry in Nigeria, the Second Republic administration of Alhaji Shehu Shagari set out in earnest to make the development of iron and steel a priority in the country's industrial sector. To achieve this objective, the Shagari administration went on to set up a Steel Development Department, with a minister of cabinet rank to oversee it. In fact, to show the place of iron and steel in the order of economic development priority of the Second Republic, the 
government did not just initiate the construction of the gigantic Ajaokuta steel complex, it went on to commence the construction of four more steel plants. These plants included the Delta Direct Reduction Complex Aladja near Warri, and the Inland Rolling Mills at Oshogbo, Jos and Katsina. However, the Ajaokuta steel plant was the most expensive, thereby easily drawing the attention of anyone studying the industrial sector of Nigeria. The Russian firm, by the name, Tiajprom Export took up the contract of constructing the plant on $13^{\text {th }}$ July, 1979. The plant was designed to have the initial production capacity of 1.3 million tonnes of steel per annum, rising to 2.6 million tonnes in the second phase and to 5.2 million in the third and final phase. The government went on to award contracts which were said to be up to N830 million for civil works and townships in the Ajaokuta steel complex. The manpower requirements of the operation of the plant was estimated at 9,000. (Ojiakor, 2014) Unfortunately, the Ajaokuta steel complex could not be completed and steel production in appreciable commercial scale has not been achieved in the country. With the absence of steel exports, Nigeria continues to rely heavily on the petroleum oil exports and revenue.

\section{A Compromised Trade Sector as an Indication of Monoculture Economy}

The developments in the agricultural and industrial sectors of the Nigerian economy have a direct influence on the trade or commercial sector, especially on exports. This is because a country can only trade with other countries that which it has comparative advantage of producing agriculturally or industrially. It is worthy to note here that different parts of the country evolved different trade patterns in the pre-colonial times and many of them were involved in significant exports or what was termed long distant trade mostly across the Sahara. North Africa is known as the sub-region to establish the first regular contact with Nigeria. This was made possible by the trans-Saharan trade. Ekundare (1973) throw light on the historical significance of the trans-Saharan trade on Nigeria and the West African sub-region when he states thus, "By the use of camels, caravan trade routes were developed across the Sahara between West and North Africa, and for a long period these routes were the only ways to and from West Africa and the outside world." 
Agajelu \& Orizu: Monoculturalism in Nigeria...

However, colonialism redirected Nigeria's foreign trade from across the Sahara to Europe. The primary motive of the British in Nigeria was to establish the colony as a base for industrial primary products and also as a market for British manufactured goods. This objective directed the British colonial economic policies in the country. The British intensified the exportation of raw materials from Nigeria and export figures soared high especially in the southern part of the country. The years between 1908 and 1910 experienced rapid growth in Nigeria's external trade in the southern parts. A similar phenomenal growth was experienced in the northern Nigeria area from 1910 onwards. The increase in exports was made possible by the colonial infrastructural policy. There was the impressive network of railways across the country, and the northern contributions on trade were effectively made possible by the extension of the railway from Minna to Kano in 1911. These contributions could be seen in the statistics of groundnut exports from the region. Whereas groundnut exports from the north was about 1,179 tons in 1910, it reached 19,288 in 1911. (Uhomoibhi, Mahadi, and Anyanwu, 2010) By the time Nigeria gained independence in 1960, it started experiencing trade deficits. This could be attributed to the deliberate colonial effort to de-industrialise the country. Therefore, at independence, instead of Nigeria depending on local production for export, it engaged in large scale importation of machinery and equipments. Nonetheless, the country soon started experiencing trade surpluses as a result of massive exports of crude oil. However, the positive outcome of the export of crude only reinforced the country's dependence on foreign capital goods and industrial raw materials, thereby precipitating long-term negative impact. Trade deficits returned beginning in mid-1970. Since then Nigeria's balance of trade has alternated between periods of deficits and of surpluses, driven by fluctuations in the global oil market and government decisions on how to spend its money. A trade surplus in 1980, for example, allowed work to continue on the new federal capital designate of Abuja, but by 1982 the surplus had become a deficit, and at the end of 1983 the country was virtually bankrupt. At the beginning of the 21st century, exports were greater than imports, but the interest on the country's external debt was so high that a truly favourable balance of trade (as opposed to one that existed on paper only) hinged at least partly on the effectiveness of debt relief.(Udo 
Ogirisi: a new journal of African studies vol. 15s 2019

and Falola, 2010) This highly unstable situation perpetuate the country's dependency on international donors and further highlights the incompetence of the leaders, who have imbibed a monocultural attitude towards the country's economy.

There has always been an effective and elaborate internal trading system in Nigeria over the years. The direction of domestic trade in staple foods is largely north-south between different ecological zones but also between major urban centres in the southeast and southwest. The southern states supply plantains, cassava, kola nuts, and fruit to the northern states, which in turn supply beans, onions, and livestock to the southern states. Yams from the central region are traded in the southern and the far northern cities. Women play a dominant role in marketing foodstuffs and manufactured goods in the southern states. Most of the food items and manufactured goods are sold in open market stalls, in small neighbourhood shops, and on the streets. Normally, the internal trading system could have helped to ensure sustainable markets for domestically produced goods hence contributing enormously to economic development through equitable distribution of income per capita. Unfortunately, such factors as overdependence on oil, inflation and unhealthy competition with imported goods have kept on undermining local production and trading.

\section{An Untapped Service Sector}

A critical look at the service sector of the Nigerian economy will show that the sector is virtually untapped. Major components of the service sector, which are science and technology, are conspicuously absent in the country's economic environment. Another highly rewarding component of the service sector, which is tourism, is virtually comatose in the country. Ironically, Nigeria has lots of tourism prospects because the country has many attractions of interest to tourists. There are miles of coastal beaches, wildlife reserves, a variety of cultures, and many museums that house artistic treasures. Obviously, the attention of the country's leaders have not been drawn in those areas because they keep staring at the direction of crude oil. 
Agajelu \& Orizu: Monoculturalism in Nigeria...

\section{Leadership of the Military and Further Economic Woes for Nigeria (Economic Policies of the Military Junta in the 1980s and 1990s)}

Nigerian economy in the 1980s and 1990s was characterised by a conspicuous monoculturism and romance with foreign donors. This basically came in form of concerted attempts to ameliorate the long ailing economy. However, some unfortunate developments in the country strained the economic relations between Nigeria and many western donor actors, thereby deepening the economic woes of the country. Such unfortunate developments were the ugly human rights situation precipitated by military dictatorships in the country. The General Sani Abacha's military junta particularly witnessed sanctions from international state and non-state actors, including prospective donor agencies, because of records of blatant human rights violations attributed to the regime. These sanctions went further to stultify oil exports and sales for the country.

The Nigerian story of economic woes, precipitated by unsound economic leadership in the second half of the 1980s up till the first quarter of the 1990s could be told within the context of the country's relations with the Bretton Woods institutions. With the oil glut that graced the Nigerian economy at the turn of the 1980s, the country was faced by the maladies that came with a monoculture economy, which relies on crude oil exportation. The situation is explicated by A. C. Agajelu, N. J. Obiakor and Leo Nnoli (2016) in the following words:

By the late 1970s and the turn of the 1980s, the global oil price experienced a drastic fall which resulted to the oil glut. Nigeria started experiencing excruciating balance of payments deficits due to sharp decline in foreign exchange earnings. The monoculture economy of the country that deepened since the exploration of petroleum in commercial quantity only served to worsen the fall of the national income. The country's Gross Domestic Product (GDP) started experiencing a steady decline. The economy of the country dipped to an all-time low and the policy makers seemed totally clueless as to measures which will save the drowning economy. The Bretton Woods Institutions 
Ogirisi: a new journal of African studies vol. 15s 2019

seemed to be the only light at the end of the tunnel especially as credit facilities was no longer flowing in from international commercial banks.

Of course the Nigerian economy experienced a major hiccup as the country's foreign exchange earnings could not take care of its import bills. During the oil boom, Nigeria was known to have engaged in heavy importation of both capital and consumer goods. This reliance on importations made the governments of the country scamper for donorship since the income of the country could no longer balance with its expenditure. However, at this point it is pertinent to show with statistics the period when the external sector of the country's economy enjoyed a favourable balance of payment. This period is regarded as the period of growth of Nigeria's merchandise trade. The positive trend is explicated in the table below:

\section{Table 2.1}

The Growth of Nigeria's Merchandise Trade, 1946-1974

\begin{tabular}{|l|l|l|}
\hline Year & Exports (Naira 000) & Import (Naira 000) \\
\hline 1946 & 49,292 & 40,918 \\
\hline 1950 & 180,446 & 123,736 \\
\hline 1955 & 265,067 & 272,238 \\
\hline 1960 & 339,427 & 431,782 \\
\hline 1965 & 536,538 & 550,788 \\
\hline 1970 & 885,365 & 756,419 \\
\hline 1971 & $1,293,338$ & $1,078,907$ \\
\hline 1972 & $1,434,212$ & 990,064 \\
\hline 1973 & $2,278,415$ & $1,224,786$ \\
\hline 1974 & $5,794,837$ & $1,737,324$ \\
\hline
\end{tabular}

Source: Federal Office of Statistics, Trade Report, Annual Abstract of Statistics and Economic Indicators; Quoted in Fajana et al, (1979)

Even though naira was not in use in the earlier period before 1970, as presented in the table 2.1, the value of imports and exports are given in naira to achieve uniformity. The table shows the advantage exports had over imports and the positive trend of balance of payment accruable. Imports only edged over exports in 1960, which was the independence year and 1965, which was a year that marked 
Agajelu \& Orizu: Monoculturalism in Nigeria...

the height of instability that characterised Nigeria's first republic. After these periods, the index became positive again. Of course, we know these years as seen in the table as the years Nigeria achieved its best economic results. The table 2.2 below justifies this assertion. The economic realities that led to the country's reliance on oil revenue and external donors are explicated in the table and explanations below:

\section{Table 2.2}

Selected Indicators of Economic Growth Performance, 1975- 1984

\begin{tabular}{|l|l|l|l|l|l|l|l|l|l|l|}
\hline Indicators & $\mathbf{1 9 7 5}$ & $\mathbf{1 9 7 6}$ & $\mathbf{1 9 7 7}$ & $\mathbf{1 9 7 8}$ & $\mathbf{1 9 7 9}$ & $\mathbf{1 9 8 0}$ & $\mathbf{1 9 8 1}$ & $\mathbf{1 9 8 2}$ & $\mathbf{1 9 8 3}$ & $\mathbf{1 9 8 4}$ \\
\hline $\begin{array}{l}\text { Aggregate } \\
\text { Output } \\
\text { GDP Growth } \\
\text { Rate (\%) }\end{array}$ & 10.7 & 10.4 & 6.6 & -5.6 & 5.9 & 0.5 & -5.2 & -5.3 & -6.7 & -0.6 \\
\hline $\begin{array}{l}\text { Domestic } \\
\text { Production } \\
\text { Index of } \\
\text { Agricultural } \\
\text { Production } \\
\text { (1975=100) }\end{array}$ & 100.0 & 93.9 & 88.7 & 88.5 & 87.2 & 89.4 & 92.4 & 91.9 & 87.9 & 91.4 \\
\hline $\begin{array}{l}\text { Index of } \\
\text { Manufacturing } \\
\text { Production } \\
\text { (1975=100) }\end{array}$ & 100.0 & 123.8 & 131.1 & 148.6 & 221.6 & 233.1 & 245.9 & 322.3 & 307.4 & 251.4 \\
\hline $\begin{array}{l}\text { External } \\
\text { Sector } \\
\text { Index of } \\
\text { Agricultural } \\
\text { Export } \\
\text { Earnings } \\
\text { (1975=100) }\end{array}$ & 100.0 & 118.6 & 162.8 & 178.8 & 202.6 & 147.2 & 48.9 & 86.1 & 186.6 & 125.1 \\
\hline $\begin{array}{l}\text { Index of Oil } \\
\text { Export } \\
\text { Earnings } \\
\text { (1975=100) }\end{array}$ & 100.0 & 138.5 & 155.0 & 118.4 & 222.7 & 296.4 & 234.1 & 175.1 & 157.8 & 193.8 \\
\hline
\end{tabular}

Source: Oyejide, Soyode and Kayode (1985)

The table 2.2 above presents data on the indicators which capture the essential elements of Nigeria's economic growth performance during the 1975-1984 decade. Three types of growth indicators are displayed in the table. The indicator of aggregate output performance is the average annual growth rate of the Gross Domestic Product (GDP). According to the trend shown by this 
indicator, the rapid inducing impact of the 1973-1974 sharp increases in crude oil prices carried through the first three years of the 1975-1984 periods. Positive and impressive GDP growth rates were thus recorded up to 1977; although the rate fell steadily during the three years from 10 percent in 1975 and 1976 down to under 7 percent in 1977. Then, there was a sharp drop to a negative growth rate of -5.6 percent in 1978. Another sharp reversal occurred in 1979 , this time in the desirable upward direction. Unfortunately, this rally turned out to be short-lived; the growth rate took a nosedive shortly thereafter and it remained in the negative range through 1984. Thus, the GDP has fallen consistently through the first half of the 1980s; and in practical terms, Nigerians have had to endure four consecutive years of generally declining standard of living. (Oyejide, Soyode and Kayode, 1985)

The other two types of indicators as shown in the table 2.1 go on to show the proximate causes of general decline in Nigeria's living standard. Two indicators attempt to track the performance of domestic production for the local market. These are the indices of agricultural production and manufacturing output. The trend of agricultural output represents a clear disaster case. Over the 10year period, agricultural output remained more or less stagnant at a level which was well below (by roughly 10 percent) the 1975 performance. Given Nigeria's rapidly growing population, the consequences of a stagnant agriculture are obvious grim. The trend of manufacturing output, according to the table, is more reassuring. Steady, though not dramatic, increases in output are recorded throughout the 1975-1984 period, except in the last year when a fairly sharp drop is shown as the index declined from 307.4 to 251.4 between 1983 and 1984, as shown in the table. This decrease of about 21 percent in manufacturing output was the ultimate reflection of the drastic shortage of industrial raw material inputs following tight control on imports which was progressively imposed from 1982 as a means of dealing with the increasingly acute shortage of foreign exchange. (Oyejide, Soyode and Kayode, 1985)

However, as indicated earlier in this paper, the proximate cause of the economic crises, which pushed Nigeria to be donor-dependent economy, are to be found in the external sector. Just as the oil (export) boom of the 1973-1975 period created the growth-inducing resources which enhanced GDP growth rate up to 1977, the impact 
Agajelu \& Orizu: Monoculturalism in Nigeria...

of subsequent events in the external sector is reflected in the GDP growth trend between 1978 and 1984. The external sector, as inferred earlier, has been dominated by oil export earnings. Foreign exchange earnings from the agricultural sector exhibited a mild upward trend until 1979, after which a marked decline occurred. This sector thus contributed somewhat to the economic crisis of the 1980s. But the real culprit clearly appears to be the oil sector. As indicated in table 2.1, particular declines in the index of oil export earnings were faithfully reflected by corresponding decreases in the GDP growth rate. For instance, as the index dropped from 155.0 to118.4 between 1977 and 1978, the GDP growth rate fell from 6.6 percent to -5.6 percent. The consecutive year to year decreases of the index between 1980 and 1983 were mirrored by similar declining GDP growth rates over the period. As the index regained an upward trend between 1983 and 1984, the GDP growth rate also improved. (Oyejide, Soyode and Kayode, 1985)

From the explications above, it has been shown that the policy-makers of Nigeria during the 1970s were either unknowledgeable of the linkage effect of international price of oil on the country's GDP and in furtherance on the county's economic growth and development, or they were simply ignorant of it. In all, the economic realities plunged the country down the dangerous lane of balance of payments deficits and its resultant economic recession. The situation made the country to look in the direction of major donors which were the Bretton Woods institutions (World Bank and the International Monetary Fund) for bailout loans.

By the turn of the 1980s, the second republic government of Alhaji Shehu Shagari was battling to revive a seriously ailing economy. Unfortunately, while efforts were made by the government to keep the country on the part of economic growth and development, other events in the international economic arena, especially the global economic recession, effectively weighed the country's economy down. The recession worsened an already bad situation of decreased oil exports and precipitated a rapid decline in commodity prices on the world market. To meet external financial commitments Nigeria was increasingly forced to borrow money from international capital market. General mismanagement of available funds made the country to suffer mounting budget deficits which, according to $\mathrm{T}$. Falolaet al (2010), rose from N3,295.6 million in 1980 to N4,882.6 
Ogirisi: a new journal of African studies vol. 15s 2019

million in 1981 and N5,373.1 million in 1982. Total government deficits increased from 16.6 percent in 1980 to 31.9 percent in 1982. The budgetary deficits were financed by borrowings and by 1983 Nigeria had already developed a scary debt profile.

In addition to going to the Bretton Woods Institutions, the Shagari's government also made some indigenous efforts to salvage the country's economy. In order to battle the downward sliding economy, the government promulgated the Economic Stabilisation (Temporary Provision) Act of 1982. This Act was promulgated primarily to reduce government expenditures and curtail imports. The president justified the Act by stating that "since government depended on oil revenue for $82 \%$ of its expenditure; the decline of oil sector has had various impacts on our domestic finance." (Agajelu, Obiakor and Leo Nnoli, 2016) In order to check importations the government went on to impose import duties where hitherto non-existent, increase the existing import duties and import licenses already issued to various categories of business persons were recalled for review. In addition, business travel allowances were cut from N2,500 and compulsory advanced deposits imposed on importers of certain commodities including food, building materials, raw materials for use in industry, spare parts and so on.

Furthermore, external borrowing by states was restricted. These economic measures became known as austerity measure. While the aforementioned internal austerity measures were being adopted, negotiations were started with the IMF for a loan. The negotiations with the IMF for a loan could not be completed by the Shagari administration as it was forcefully replaced by the military junta led by Gen. Muhammadu Buhari.

The Buhari's military government began renegotiation of loan agreements between the country and the IMF. Nonetheless, the government appeared to be indecisive on whether to accept the IMF conditionality and go for the loan or whether to reject the loan because of what was regarded as the IMF draconian conditionality. This indecision is seen as one of the economic short-comings of the Gen. Buhari military administration. Falola et al (2010) capture the situation in the following words:

Perhaps the most serious weakness of the economic programme of the Buhari administration was its failure to evolve any overall strategy for dealing 
Agajelu \& Orizu: Monoculturalism in Nigeria...

with Nigeria's external indebtedness which at the time peaked at 20 billion dollars. Faced with an option of taking an additional loan with assorted conditions from the International Monetary Fund, and a rejection of the loans with self-imposed economic policies which would radically depart from the existing policies, the Buhari administration simply prevaricated.

The military junta of Buhari was toppled in 1985 to be replaced by another junta led by Gen. Ibrahim Badamosi Babangida, popularly known as IBB. The IBB administration immediately made known its commitment to tackle the economic difficulties which faced the country and therefore, did not hesitate to open up for loan negotiations with the IMF. Agajelu, Obiakor and Nnoli (2016) describe the changes the IBB government introduced to the Nigerian economy in the following words:

However, the coming to power of General Ibrahim Babangida marked a turning in the annals of economic restructuring in Nigeria. In its efforts to break the icy relationship between Nigeria and the IMF, the regime instituted a national debate on the desirability of Nigeria obtaining a 2.5billion U.S dollar loan with the accompanying conditionality. It was reported that though the delegates rejected the loan during the national debate, Babangida went ahead and implemented the Structural Adjustment Programme which was the conditionality for procurement of the IMF loan.

Even though there was what appeared to be unpopular response to the IBB's desire to accept the IMF loan under the Structural Adjustment Programme (SAP), the government went ahead to adopt and launch SAP in June 1986. The adoption of SAP and the obvious hardship that came with the programme strengthened the voice of proponents of dependency theory. The conditionality of SAP has been described as draconian and has been deeply criticised both within and outside Nigeria. In the context of the IMF, conditionality refers to the policies a member is expected to follow in order to 
Ogirisi: a new journal of African studies vol. 15s 2019

secure access to the resources of the Fund, in essence to the conditions that have to be met for gaining access to the financial resources of the Fund. These policies are intended to help ensure that the member country will overcome its external payments problem and thus be in a position to repay the Fund in a timely manner. The policies towards economic reforms as contained in SAP as at the 1980s included:

- Import substitution

- Privatisation and commercialisation

- Trade liberalisation

- Withdrawal of subsidies

- Currency devaluation (Edwards, 1989)

The IBB's administration of proposed certain objectives for the implementation of SAP. These objectives are documented by Falola et al (2010) as thus:

- To restructure and diversify the productive base of the economy in order to reduce dependence on the oil sector and on imports;

- To achieve fiscal balance of payments viability, that is to say, reduction and, possibly total elimination of budget deficits;

- To lay the grounds for a sustainable non-inflationary or minimal inflationary growth;

- To lessen the dominance of unproductive investments in the public sector, and improve the sector's efficiency as well as intensify the growth potential of the private sector; and

- To reduce the strangulating regime of administrative controls in the economic sector of national life.

The effects of SAP on the Nigerian economy have been a subject of intensive debate among both economists and lay people. However, its direct impact on the citizenry, which came in form of low living conditions attributed to the devaluation of the naira, inflation, removal of subsides, among others, made the programme a subject of intense criticism.

By 1991, the economy of Nigeria was characterised by the effects of structural adjustment. The government claimed that deregulation would boost domestic productivity thereby diversifying the economy. It was particularly expected that agricultural production would experience a boost. However, there are indications 
Agajelu \& Orizu: Monoculturalism in Nigeria...

that the agricultural sector generally remained sluggish even though official statistics suggest an absolute increase in the output of commodities like cotton and cocoa. Devaluation of the naira meant increased cost for farming communities, both of farming inputs and consumer goods. More significantly, the removal of subsidy on fertilisers, seeds, farm equipment and pesticides added to the increased costs suffered by farmers by the 1990s. Furthermore, the middlemen took advantage of the removal of the marketing boards to impose their will on the countryside to the detriment of the peasantry.

The industrial sector was particularly hit hard by the structural adjustment, especially by 1991. There was diminished industrial capacity utilisation due to the devaluation of the naira and the resultant inflation. Akin Fadahunsi et al (1996) reports that the industrial sector was so badly affected by the adjustment programme to the point that capacity utilisation in several cases fell below their pre-adjustment levels. The situation was exacerbated by trade liberalisation which made Nigeria a dumping ground for foreign producers. Furthermore, the collapse of consumer purchasing power meant an increase in unsold stocks in manufacturers' warehouses. The resultant effect of this was large-scale factory closures across Nigeria in the 1990s.

Some argue that the boom in the banking and financial sector witnessed since 1986 was a positive effect of SAP due to deregulation. However, Fadahunsi et al (1996) argue that this boom only heightened speculative activities, especially with regard to naira exchange rate. They went further to state that in the period up to 5 March 1992, bankers, especially merchant bankers, were able to earn a rent of up to N8 on the dollar by trading dollars (and other hard currencies) which they bought from the Central Bank of Nigeria at about N10 to the dollar for between N15-N18 to the dollar. The bureau de change which they set up also prospered on such huge rents. The decision of the CBN to devalue on 5 March 1992 and become an active trader in the foreign exchange market failed significantly to put a decisive end to this kind of rent-seeking. Indeed, a new gap opened almost immediately between commercial/central bank naira exchange rate and the parallel market bureau de change rates. As of the end of December 1993, whereas the central bank rate for one US dollar was N21.9, the parallel 
market/bureau de change rate was N47. In 1995, while the CBN rate stood at N22 to the dollar, the parallel market rate rose as high as N82 to one dollar. This trend marked the instability which hit the banking and financial sector of the economy in the 1990s as a result of the SAP. In all, SAP failed to be an agent of the highly needed economic diversification. Instead it perpetuated the country's dependency on foreign donors and the rot in the economy continued ever since.

The return to civilian government promised some new dimensions in solving the Nigerian economic problems. While the military dictatorships were characterised by authoritarianism which manifested in uncontested decrees, the civilian government had the promise of incorporating experts and technocrats to help solve the country's economic malady. By the time the Chief Olusegun Obasanjo's administration emerged in 1999, there appeared to be a light at the end of the long dark tunnel. Taking cognizance of the deplorable living conditions of Nigerians and the negative effects of SAP on the industrial sector of the economy, Obasanjo stated the following as top of his economic policy objectives:

- Emphasis on developing manufacturing industries as opposed to agriculture,

- Movement of labour from rural to urban industrial areas,

- Less reliance on imported goods in preference to home produced goods,

- Revision or abolition of the outdated land tenure system that hindered the acquisition of land for industrial projects, and

- Establishment of a stable political system. (Ojiakor, 2014)

\section{Conclusion}

In as much as Obasanjo's efforts achieved varied results, the monoculture economy trend, which continually hinder Nigeria's bargaining power in a free trade international economic system, persisted. Subsequent governments of Alhaji Umaru Musa Yar'dua, Dr. Goodluck Ebele Jonathan and Muhammadu Buhari (who was the Nigeria's president in 2017) attempted to adopt different measure to make a difference in the Nigerian economy and ensure positive balance of payments. However, the fall in the global oil price in 2015 and the concomitant economic recession that hit Nigerian 
Agajelu \& Orizu: Monoculturalism in Nigeria...

economy shows that much progress has not been made in the area of economic diversification.

We have identified certain factors that undermine Nigerian economy and such factors are the unhealthy monoculture economy system, political instability, inflation, heavy importation of capital and non-capital goods and so on. The question now becomes: what are the trends in the Nigerian environment that precipitated these factors? Empirical observation shows that the unhealthy trends that keep the country economically crippled among other things include, corruption, maladministration, misplaced priorities, nepotism, despotism, disintegration, and unpatriotic overtures. From the first republic, each administration in Nigeria had been characterised by the above mentioned anti-nation building traits. This made Chinua Achebe (1983) to write thus:

The trouble with Nigeria is simply and squarely a failure of leadership. There is nothing basically wrong with the Nigerian character. There is nothing wrong with the Nigerian land or climate or water or air or anything else. The Nigerian problem is the unwillingness or inability of its leaders to rise to the responsibility, to the challenge of personal example which are the hallmarks of true leadership.

*Abuoma C. Agajelu, Department of History and International Studies, Nnamdi Azikiwe University, Awka

\&

*Oluchukwu N. Orizu, Department of History and International Studies, Nnamdi Azikiwe University, Awka 


\section{References}

Achebe, Chinua (1983) The Trouble with Nigeria, London: Heinemann.

Agajelu, Abuoma C., Obiakor, Nwachukwu J., and Nnoli, Leo O. (2016): "A History of the IMF-Nigeria Relations Since the 1970s," International Journal for Social Studies Vol. 2, No. 8 ISSN (Online) 2455-3220.

Buira, Ariel (2003) "An Analysis of IMF Conditionality," A Paper Prepared for the XVI Technical Group Meeting of the Intergovernmental Group of 24 Port of Spain, Trinidad and Tobago.

Edwards, Sebastian (1989) "Structural Adjustment Policies in Highly Indebted Countries," in Jeffery D. Sachs ed., Developing Country Debt and Economic Performance, Volume 1: The International Financial System, Chicago: University of Chicago Press.

Ekundare, R. Olujemi (1973) An Economic History of Nigeria, 1860-1960, London: Methuen \& Co Ltd.

Fadahunsi, Akin Olukoshi, Adebayo Momoh, Abubakar and Babawale, Tunde (1996) "Nigeria Beyond Structural Adjustment: Towards a National Popular Alternative Development Strategy," in Akin Fadahunsi and Tunde Babawale, Nigeria Beyond Structural Adjustment: Towards a Popular Democratic Development Alternative, Lagos: Panaf Publishing Inc.

Fajana, F.O., Tomori, S., Ukpong, I.I., Fapohunda, E.R., Umo, J. Ubogu, R.E. and Adejugbe, A. (1979) Structure of the Nigerian Economy, London: The Macmillan Press LTD.

Falola T., Uhomoibhi, M. Mahadi, A. and Anyanwu, U. (2010) History of Nigeria 3: Nigeria in Twentieth Century, Lagos: Longman.

Lawal, A.A. (1997) "The Economy and the State from Pre-Colonial Times to the Present," in Akinjide Osuntokun and Ayodeji Olukoju, eds., Nigerian Peoples and Culture, Ibadan: Davidson Press.

Njoku, Onwuka (2014) Economic History of Nigeria: $19^{\text {th }}$ and $21^{\text {th }}$ Centuries Second Edition, Enugu: Magnet.

Nwankwo, Agwuncha Arthur (1999) Nigeria: The Stolen Billions, Enugu: Fourth Dimension Publishers. 
Agajelu \& Orizu: Monoculturalism in Nigeria...

Ojiakor, Ngozi (2014) Social and Political History of Nigeria 19702006, Enugu: EWANS Press.

Oyejide, T.A., Soyode A.and Kayode, M.O. (1985) Nigeria and the $I M F$, Ibadan: Heinemann Educational Books Nigeria Limited.

Udo, Reuben Kenrickand Falola, Toyin O. (2010) "Nigeria: Economy", Encyclopaedia Britannica, Encyclopaedia Britannica Student and Home Edition, Chicago: Encyclopaedia Britannica, (e-version). 